\title{
Implications of population dynamics and interspecific competition for harvest management of the seaweed Laminaria
}

\author{
Barry D. Smith* \\ Nova Scotia Department of Fisheries, P.O. Box 2223, Halifax, Nova Scotia B3J 3C4, Canada
}

\begin{abstract}
Growth rates and population variables of the seaweeds Laminaria longicruns De la Pylaie and L. digitata (Hudson) Lamouroux were monitored from July 1980 until April 1983 within adjacent harvested and control plots in southwestern Nova Scotia, Canada. Faster growth rates within the harvested plot, relative to the control plot, for new recruits of both species were detected only during the first year following a September 1980 total harvest of both species. Since standing crop had nearly recovered to pre-harvest levels after $1 \mathrm{yr}$, the increased growth rate was attributed to reduced standing crop during the first year post-harvest. Analysis of the relationship between each species summer canopy biomass and the density of the most recent year-class developing in the sub-canopy at the same time provided evidence for interspecific competition, and provided parameter estimates for the relationship. A stochastic model of this 2 -species interaction using reliable data on growth, recruitment, and mortality predicts long-term persistence of both species in the absence of harvesting, or other disturbances. Following total harvest, $L$. longicruris is initially more abundant than $L$. digitata, but an increasing canopy of $L$. digitata diminishes the dominance of $L$. longicruris over a period of 3 to $5 y r$. Annual harvesting of only the canopy of $L$. longicruris (a practical and perhaps technically preferable strategy) produces only $4 \%$ of the yield for a total annual harvest. Annual harvesting of the canopy of $L$. longicruris plus $L$. digitata produces only $11 \%$ of the yield for a total annual harvest. These lower yields result from a large decrease in $L$. longicruris growth rate with increased density. This feature diminishes the effectiveness of removing $L$. digitata to reduce competition with faster growing $L$. longicruris. The need for controlled and monitored experimental harvests to evaluate these predictions is discussed, as is the need for more functional analyses of seaweed systems.
\end{abstract}

\section{INTRODUCTION}

Smith (1985) concluded that 2 yr were required for Laminaria longicruris De la Pylaie and L. digitata (Hudson) Lamouroux to attain pre-harvest population characteristics after a September 1980 total harvest of both species. A yearly harvest was recommended for maximizing yield. Also, there was no irreversible change in the understory community as a result of a single incident of canopy removal.

Several questions regarding harvesting remain unanswered. We do not known the effects of lost productivity and habitat on organisms in higher trophic levels (Wharton \& Mann 1981); and we do not know

\footnotetext{
- Present address: Department of Fisheries and Oceans, Fisheries Research Branch, Pacific Biological Station, Nanaimo, British Columbia V9R 5K6, Canada

the effects of successive yearly harvests on the structure of the understory community, or the resilience of the 2 Laminaria species. For instance, Chapman (1984) provides evidence that an understory of small rhodophytes can inhibit development of Laminaria sporophytes.

This paper documents further efforts to understand Laminaria population dynamics in Nova Scotia, Canada, by predicting the effects of different harvest policies on the recovery and relative success of both Laminaria species. This is accomplished with a stochastic simulation model which uses data collected from 1980 to 1983 when information was acquired for both species on recruitment, growth, mortality, and interspecific competition. Using reliable estimates (including standard errors) of population parameters for both species, some effects of biomass reduction on population structure and harvest yield are predicted 
for different harvest policies. Evaluation of these predictions is required, and can be achieved through controlled and monitored experimental harvesting.

\section{SITE DESCRIPTION}

The study site faces west off Ram Island, a small island in Lobster Bay, Nova Scotia $\left(43^{\circ} 41^{\prime} N_{\text {i }}\right.$ $65^{\circ} 62^{\prime} \mathrm{W}$ ), which was chosen for high Laminaria standing crop, and accessibility (Fig. 1). The site is characterised by annual temperatures and salinities ranging

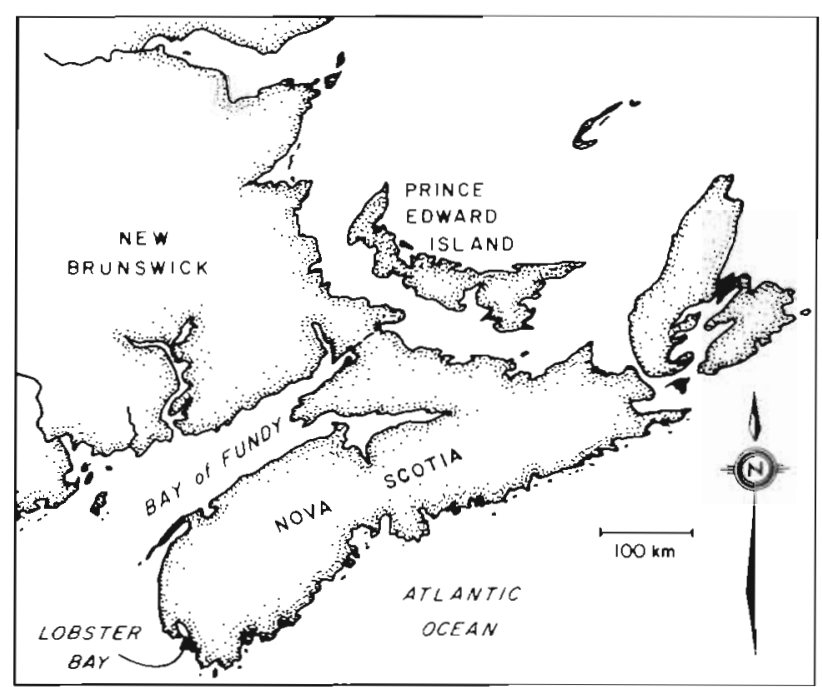

Fig. 1. Study area in Atlantic Canada

from -1 to $17^{\circ} \mathrm{C}$ and 28 to $33 \%$, respectively. The substrate is rocky and mean substrate relief is $25.5 \pm$ $13.9 \mathrm{~cm}(\mathrm{n}=1200)$ for the harvest and control plots at 3 to $4 \mathrm{~m}$ below mean sea level (MSL), the depth range relevant to this study. The composition of the seaweed community at this site was described in Smith (1985).

\section{METHODS}

Fig. 2 shows the layout and sampling format at Ram Island. Precise location of the experimental plots and permanent quadrats for monitoring tagged plants was facilitated by placing flagged aluminum eye-bolts in the substrate. All field maintenance, collections and measuring required the use of SCUBA.

Harvest and control plot standing-crop assessments were obtained for Laminaria longicruris and L. digitata in the summers of 1980 to 82 . All Laminaria plants greater than $50 \mathrm{~cm}$ total length were counted within each of the forty $0.25 \mathrm{~m}^{2}$ quadrats comprising each of

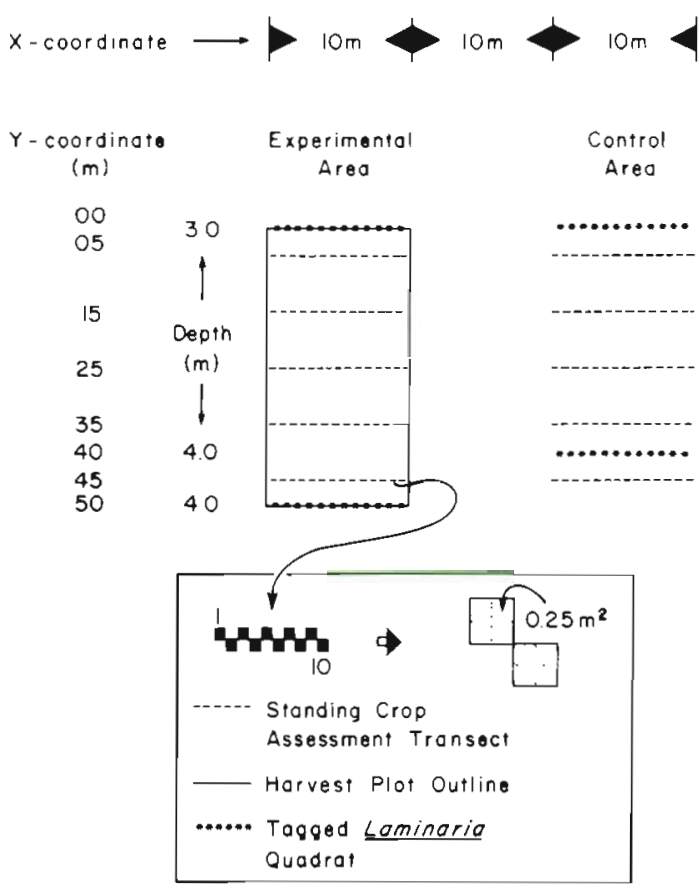

Fig. 2. Diagrammatic portrayal of study site at Ram Island, Nova Scotia, Canada

assessment transects for each plot. Fifty $\mathrm{cm}$ is approximately the smallest size of plant that could be assessed effectively and efficiently during field sampling. Following Laminaria counting, the most representative $0.25 \mathrm{~m}^{2}$ quadrat of each $1.0 \mathrm{~m}^{2}$ quadrat was collected using an underwater airlift fitted with a $3 \mathrm{~mm}$ mesh collecting bag (Foreman 1977). The choice of collected quadrats was occasionally deliberately biased toward obtaining sufficient data on Laminaria population statistics. All Laminaria plants within each collected quadrat were sorted to species and wet weighed. Individual plants of $L$. longicruris and $L$. digitata greater than $50 \mathrm{~cm}$ total length were counted and the following variables measured: stipe length, lamina length, lamina width, stipe weight, lamina weight. Environmental conditions and substrate characteristics were also recorded. On 3 September 1980, following the initial control and harvest plot assessments, all Laminana plants within and overlapping the harvest plot were detached at or near the holdfast by SCUBA divers using kitchen knives.

Laminaria growth and mortality data were obtained by regularly counting and measuring tagged plants of each species within 4 permanent quadrats $(1 \times 10 \mathrm{~m})$. All plants greater than $50 \mathrm{~cm}$ total length within 2 control plot quadrats and 2 harvest plots quadrats were tagged with individually numbered cable ties and first measured in May 1981. For each plant, stipe length, lamina length, and lamina width were measured. 


\section{RESULTS}

\section{Laminaria recovery and survivorship}

Table 1 presents some descriptive statistics for the Laminaria populations in the harvest $(\mathrm{H})$ and control (C) plots before and after the total harvest on 3 September 1980. By summer 1981 L. longicruris had recovered to $96 \%$ of its pre-harvest standing crop. The plants were smaller, but this was compensated by a $36 \%$ increase in plant density. L. digitata regrew only $25 \%$ of its standing crop by summer 1981, but had recovered to pre-harvest population characteristics by summer 1982.

Survivorship curves for Laminaria longicruris and $L$. digitata are presented in Fig. 3. There was no consistent difference in mortality rates for plants at 3 and $4 \mathrm{~m}$ below MSL, so these data are combined within each plot. Table 2 summarizes survivorship statistics for both species.

Differences in mortality rates for each species are evident. For Laminaria longicruris the best model is exponential decline, suggesting that the risk of mortality is independent of age, but possibly not density, because the first year post-harvest mortality rate is about one half of that in a mature Laminaria community. For $L$. digitata the linear mortality model indicates that the risk of mortality increases with age and suggests that senescence or size are major factors contributing to the death of $L$. digitata.
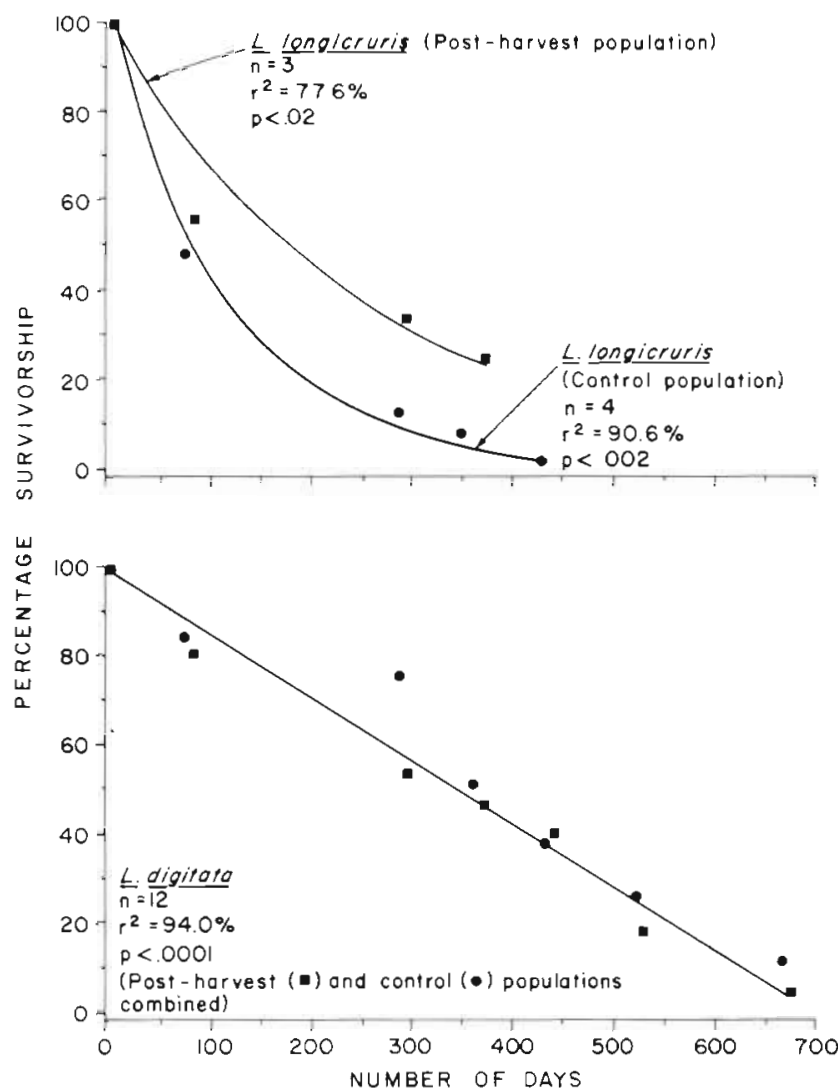

Fig. 3. Laminaria longicruris and $L$. digitata. Survivorship curves for populations at Ram Island. See Table 2 for summary of survivorship parameters

Table 1. Laminaria longicruris and L. digitata. Population characteristics of plants $>50 \mathrm{~cm}$ total length within the harvest (H) and control (C) plots at Ram Island during summers 1980-82. (1980= pre-harvest)

\begin{tabular}{|c|c|c|c|c|c|}
\hline & $1980(\mathrm{H}+\mathrm{C})$ & H 1981 & C 1981 & H 1982 & C 1982 \\
\hline \multicolumn{6}{|l|}{ L. longicruris } \\
\hline Number of plants collected & 602 & 147 & 96 & 147 & 41 \\
\hline Mean standing crop $\left(\mathrm{kg} \mathrm{m}^{-2}, \text { wet }\right)^{d}$ & 6.15 & 5.92 & 2.81 & 8.16 & 4.83 \\
\hline $1 \mathrm{SE}$ of mean & 1.18 & 1.44 & 0.79 & 1.77 & 1.52 \\
\hline Median plant length $(\mathrm{cm})$ & 209 & 203 & 156 & 333 & 371 \\
\hline Mean plant length $(\mathrm{cm})$ & 270 & 246 & 244 & 332 & 320 \\
\hline Median plant weight (g, wet) & 179 & 170 & 914 & 535 & 602 \\
\hline Mean plant weight (g, wet) & 406 & 287 & 389 & 692 & 725 \\
\hline Mean plant density $\left(\mathrm{n} \mathrm{m}^{-2}\right)$ & 15.2 & 20.7 & 7.2 & 11.8 & 6.7 \\
\hline $1 \mathrm{SE}$ of mean & 1.5 & 2.6 & 1.4 & 1.7 & 1.5 \\
\hline \multicolumn{6}{|l|}{ L. digitata } \\
\hline Number of plants collected & 198 & 56 & 119 & 104 & 127 \\
\hline Mean standing $\operatorname{crop}\left(\mathrm{kg} \mathrm{m}^{-2}, \text { wet }\right)^{d}$ & 1.76 & 0.44 & 2.91 & 1.96 & 3.15 \\
\hline $1 \mathrm{SE}$ of mean & 0.33 & 0.12 & 0.41 & 0.37 & 0.51 \\
\hline Median plant length $(\mathrm{cm})$ & 119 & 94 & 132 & 159 & 170 \\
\hline Mean plant length $(\mathrm{cm})$ & 136 & 99 & 139 & 147 & 164 \\
\hline Median plant weight (g., wet) & 128 & 78 & 142 & 272 & 427 \\
\hline Mean plant weight ( $g$, wet) & 391 & 101 & 372 & 347 & 511 \\
\hline Mean plant density $\left(\mathrm{n} \mathrm{m}^{-2}\right)$ & 4.5 & 4.4 & 7.8 & 5.7 & 6.2 \\
\hline $1 \mathrm{SE}$ of mean & 0.5 & 0.7 & 1.2 & 1.1 & 0.8 \\
\hline
\end{tabular}


Table 2. Laminaria longicruris and $L$. digitata. Summary of survivorship statistics for plants $>50 \mathrm{~cm}$ total length at Ram Island from 1980-83. Monitoring began in late May 1981

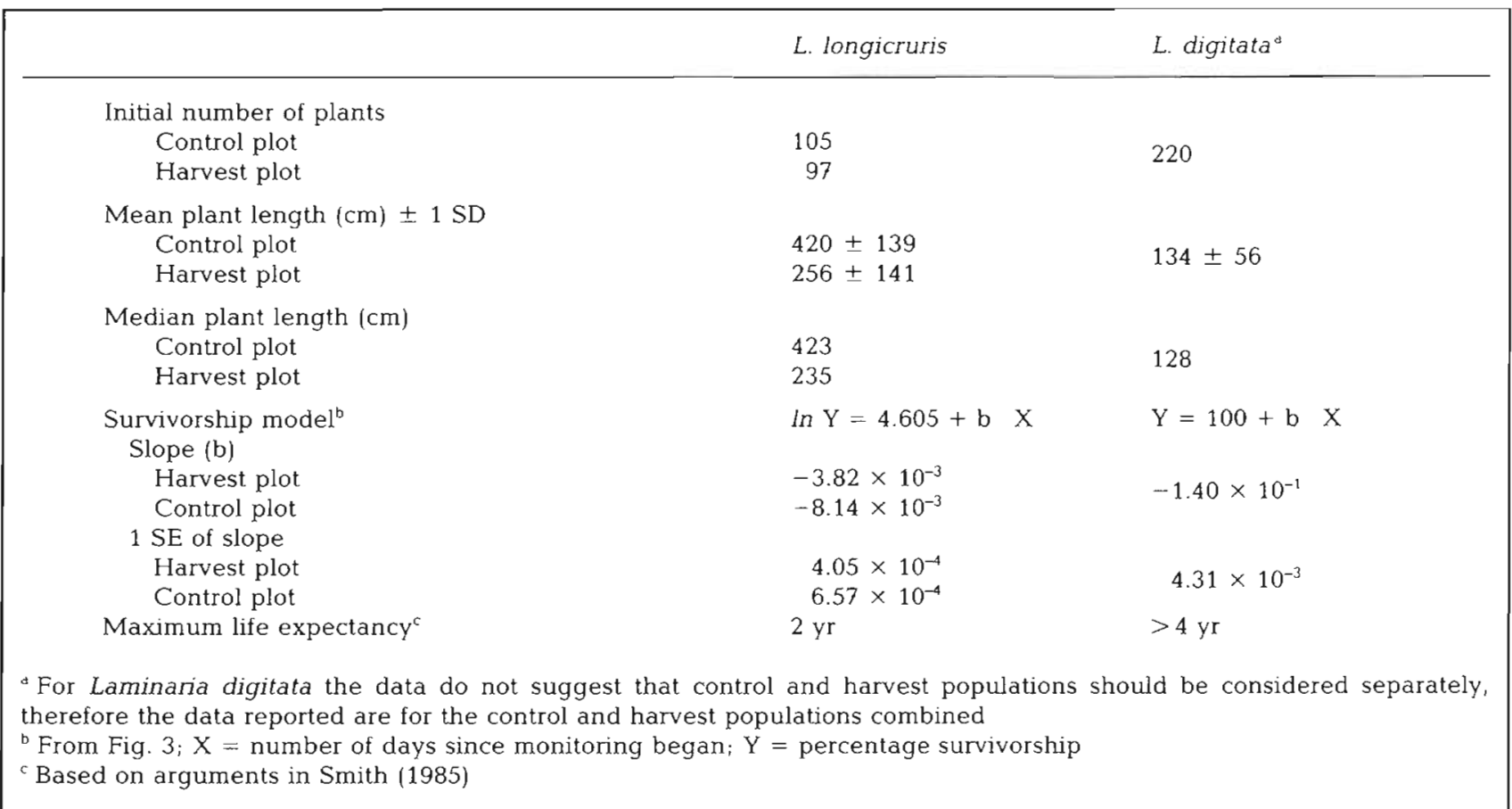

\section{Laminaria growth enhancement by canopy removal}

Fig. 4 and 5 present weight-specific daily net growth rates for Laminaria longicruris and $L$. digitata, respectively, and indicate the least-squares quadratic model, the differentiated form of the logistic growth model. Plant weight was calculated from lamina length and lamina width using the linear regression for these

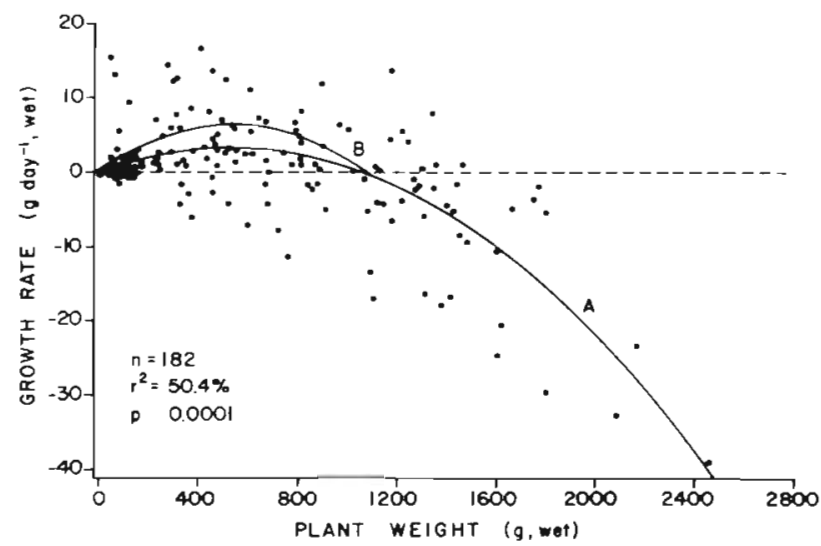

Fig. 4. Laminaria longicruris. Weight-specific daily growth rates for plants $>50 \mathrm{~cm}$ total length within a mature population (A) at Ram Island. Predicted growth rates within a first year post-harvest population are given by Curve B. Parameter estimates for both curves are listed in Table 3

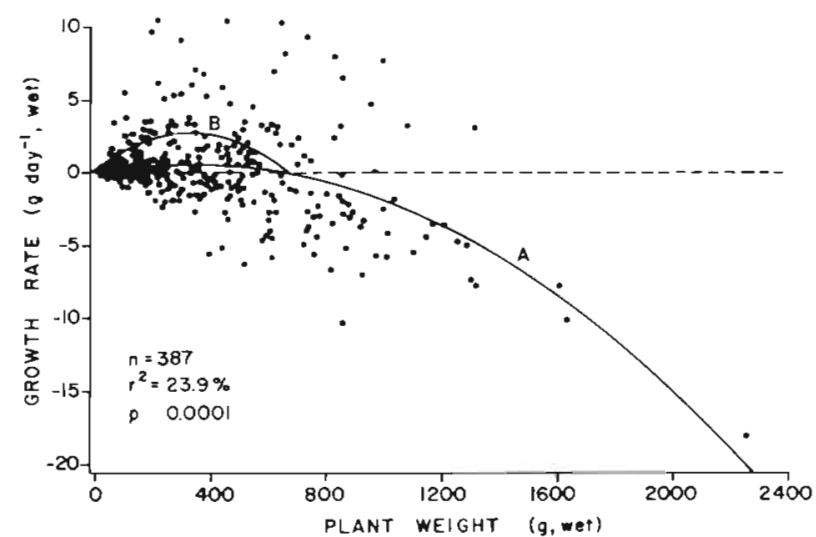

Fig. 5. Laminaria digitata. Weight-specific daily growth rates for plants $>50 \mathrm{~cm}$ total length within a mature population (A) at Ram Island. Predicted growth rates within a first year postharvest population are given by Curve B. Parameter estimates for both curves are listed in Table 3

variables introduced in Smith (1985). Daily net growth rates are mean rates between sampling dates. The I and $\mathrm{k}$ parameter estimates for the equivalent logistic model are presented in Table 3 . In this application, $r=$ intrinsic growth rate of an individual plant; $k=$ its maximum weight, i.e. when the growth and erosion processes (Mann 1973) occur at the same rate. The logistic model is particularly useful because it models 
Table 3. Laminaria longicruris and L. digitata. Logistic parameter estimates ( $\pm 1 \mathrm{SE}$ ) for plants $>50 \mathrm{~cm}$ total length growing within a mature canopy (at least 1 yr old), and in the year following a total Laminaria harvest at Ram Island. The quadratic model is: daily growth rate $\left(g \mathrm{~d}^{-1}\right)=\mathrm{r}$. plant weight - $\left[(\mathrm{r} / \mathrm{k}) \cdot(\text { plant weight })^{2}\right] . \mathrm{r}=$ intrinsic growth rate; $\mathrm{k}=$ maximum plant weight

\begin{tabular}{lcc|}
\hline Logistic parameters & L. longicruris & L. digitata \\
\hline $\mathrm{r}$ mature $\left(\mathrm{d}^{-1}\right)$ & $1.25 \times 10^{-2} \pm 1.44 \times 10^{-2}$ & $3.80 \times 10^{-3} \pm 5.96 \times 10^{-4}$ \\
$\mathrm{r}$ post-harvest $\left(\mathrm{d}^{-1}\right)$ & $2.38 \times 10^{-3} \pm 2.74 \times 10^{-3}$ & $16.32 \times 10^{-3} \pm 25.63 \times 10^{-4}$ \\
$\mathrm{k} \quad(\mathrm{g}$, wet $)$ & $1073 \pm 155$ & $675 \pm 129$ \\
\hline
\end{tabular}

the net growth rate as the summation of the growth and erosion processes.

The growth data presented here were obtained from tagged plants of various sizes growing within a Laminaria community at least 1 yr old. In order to determine if standing-crop reduction affected plant growth rates, the growth models in Fig. 4 and 5 were used to predict, backward in time, the most likely times of initial appearance for plants of both Laminaria species that comprised the $1 \mathrm{yr}$ post-harvest plot (H1981). Fig. 6 depicts the probability distribution for the times of first appearance of plants ca $50 \mathrm{~cm}$ total length (15 g wet $\mathrm{wt}$ ), based on the logistic growth

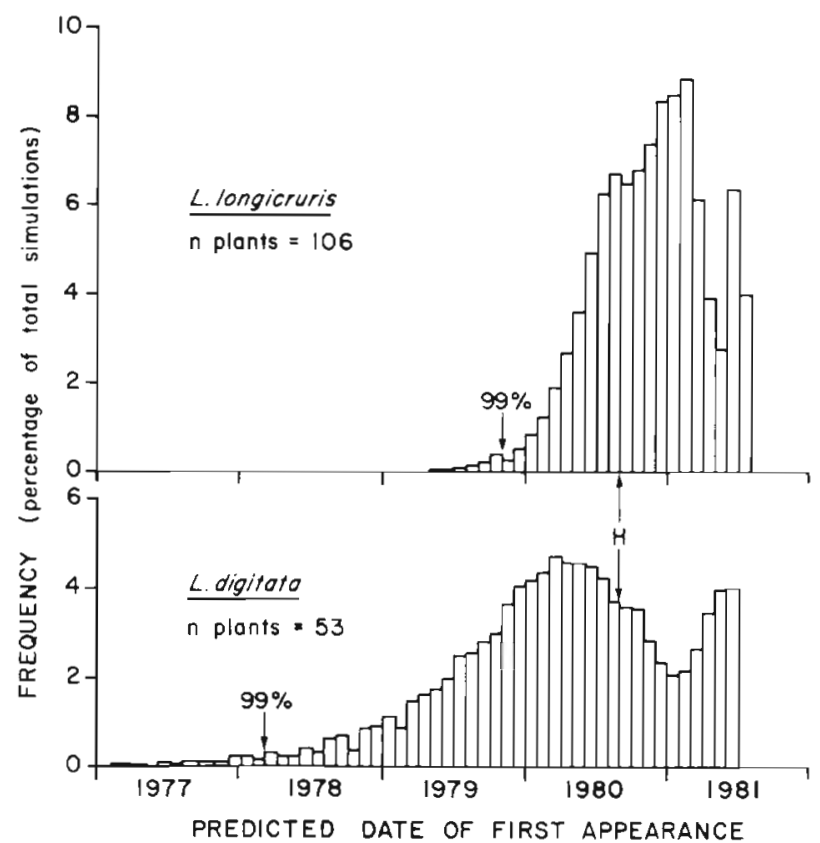

Fig. 6. Laminaria longicruris and L. digitata. Distribution of back-predicted dates for plants to be $50 \mathrm{~cm}$ total length following a Sep 1980 total harvest $(\mathrm{H})$ of both species. Plants were first monitored during summer 1981. Predictions are made using logistic growth parameters estimated from growth rates measured in mature populations of both species (Table 3). Uncertainty in parameter estimates is included by generating 100 stochastic predictions incorporating standard errors for each plant. The 99th percentile is indicated. See text for interpretation model, and the measured wet weight of the plants in H1981. Probability distributions for the time of first appearance for the H1981 populations (Fig. 6) were calculated by performing 100 simulations for each plant incorporating normally distributed statistical error of the parameter estimates.

From Fig. 6, $27 \%$ of Laminaria longicruris plants, and $68 \%$ of the L. digitata plants, in H1981 were predicted to be $50 \mathrm{~cm}$ in length before 3 September 1980 , the date the plot was harvested. Since no plants that size should have survived the harvest, the difference must be attributed to the faster growth of plants that appeared following the harvest relative to plants growing in a mature Laminaria community. Two modes are evident for both species in Fig. 6. The mode on the right represents the recruitment of the most recent year-class in spring 1981 . The mode on the left represents the peak of new recruitment following the 3 September 1980 harvest that was visually confirmed in early December 1980. At this time, several plants exceeding $2 \mathrm{~m}$ in total length were observed.

Adjustment of the distribution of times of first appearance predicted in Fig. 6 to conform with the pattern observed in nature requires an increase in the $r$ parameter for Laminaria longicruris of a factor of 1.9, and for $L$. digitata, a factor of 4.3. This was determined by gradually increasing $\mathrm{r}$ and re-simulating until $99 \%$ of the predicted start times occurred after 3 September 1980. Although L. longicruris is intrinsically a faster growing plant than $L$. digitata, $L$. digitata receives more benefit from standing-crop reduction. Estimated growth models for plants growing during the year following harvesting are presented as Curves B in Fig. 4 \& 5 .

\section{Competition between Laminaria longicruris and $L$. digitata}

To determine if the canopies of Laminaria longicruris and $L$. digitata influenced the recruitment of the most recent year class of each species developing below the canopy it was necessary to distinguish yearclasses for both species. Using the method of Cassie 
(1954) to separate frequency distributions, it was determined that, for $L$. longicruris, $311 \mathrm{~cm}$ was the total length that bisected mature populations (at least $2 \mathrm{yr}$ old) into plants less than, and greater than, 1 yr old. For L. digitata the equivalent total length was $129 \mathrm{~cm}$. Throughout this paper, plants less than 1 yr old will be said to form the sub-canopy while those more than 1 yr old will be said to form the canopy. Fig. 7 and 8 summarize the total length frequency distributions for

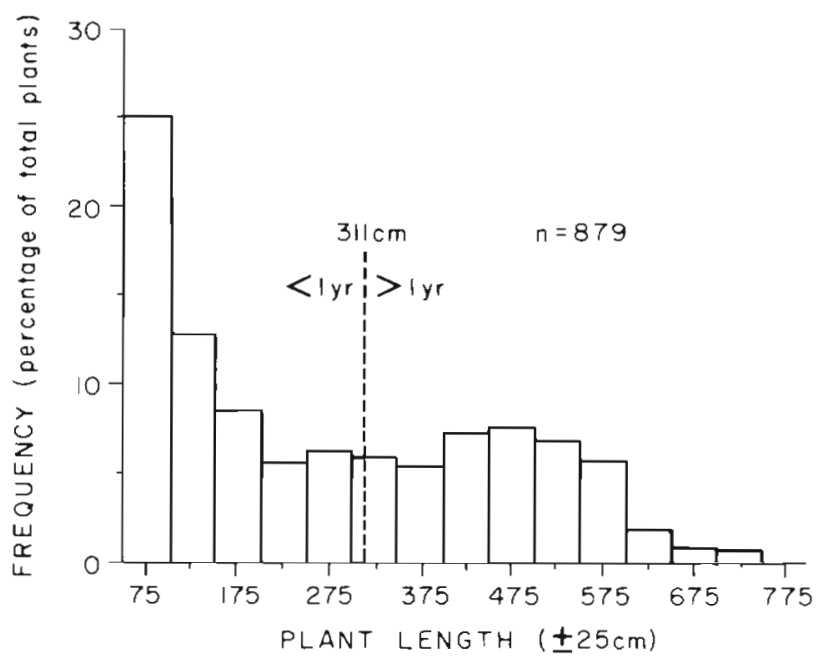

Fig. 7. Laminaria longicruris. Frequency distribution of total lengths for plants within mature populations in harvest and control plots at Ram Island (excludes only $\mathrm{H} 1981$ )

both Laminaria species within the mature populations at Ram Island, from which these determinations were made. The only plot-year sample excluded was the harvested plot in 1981 (H1981), since it only contained plants approaching $1 \mathrm{yr}$ of age which were experiencing faster growth. The age determinations are based on arguments in Smith (1985).

For both species, the influence of canopy biomass on

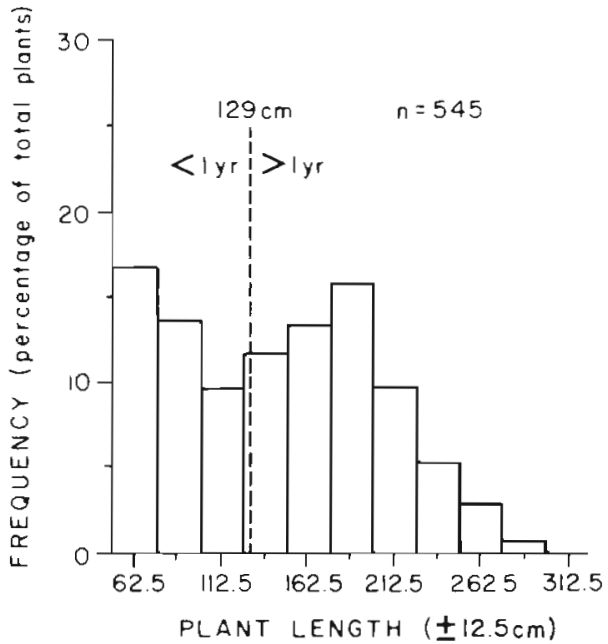

Fig. 8. Laminaria digitata. Frequency distribution of total lengths for plants within mature populations in harvest and control plots at Ram Island (excludes only H1981)

recruitment success in the sub-canopy was evaluated by regressing sub-canopy density on the canopy biomass of each species. Each data point is the mean density, or biomass, of each standing crop assessment transect within each of the 6 plot-year samples. By combining the information in each transect, sampling variability is reduced, and the data should more accurately represent canopy and sub-canopy interactions for each transect. The importance of having an appropriate scale of resolution for studying kelp dynamics is clearly explained by Dayton \& Tegner (1984). Preliminary evaluation of the data indicated they were lognormally distributed so all analyses were performed on the natural logarithm of the dependent variable.

Table 4, and Fig. $9 \& 10$, present the results of these analyses. It could not be shown that the density of new recruits of Laminaria longicruris or L. digitata develop-

Table 4. Laminaria longicruris and $L$. digitata. Parameter $(a, b)$ estimates and probability level $(p)$ for the effect of the canopies on the success of the most recent year class developing in the sub-canopy. For all cases $\mathrm{n}=30$. The linear model is: $\ln \left(\mathrm{n} \mathrm{m}^{-2}+1\right)$ $=\mathrm{a}+\mathrm{b}$ canopy biomass

\begin{tabular}{|c|c|c|c|c|c|c|}
\hline & \multicolumn{6}{|c|}{ Canopy biomass ${ }^{\mathrm{a}}\left(\mathrm{g} \mathrm{m}^{-2}\right.$, wet $)$} \\
\hline & \multicolumn{3}{|c|}{ L. longicruris } & \multicolumn{3}{|c|}{ L. digitata } \\
\hline & $\mathrm{p}$ & a & $\mathrm{b}$ & $\mathrm{p}$ & a & b \\
\hline \multicolumn{7}{|c|}{ Density of new recruits in the sub-canopy ${ }^{d}\left(\mathrm{n} \mathrm{m}^{-2}\right)$} \\
\hline $\begin{array}{l}\text { L. longicruris } \\
1 \mathrm{SE}\end{array}$ & 0.38 & $\begin{array}{c}1.66 \\
2.48 \times 10^{-1}\end{array}$ & $\begin{array}{l}3.13 \times 10^{-5} \\
3.48 \times 10^{-6}\end{array}$ & 0.01 & $\begin{array}{c}2.35 \\
2.41 \times 10^{-1}\end{array}$ & $\begin{array}{r}-1.89 \times 10^{-4} \\
6.70 \times 10^{-5}\end{array}$ \\
\hline $\begin{array}{l}\text { L. digitata } \\
1 \mathrm{SE}\end{array}$ & 0.81 & $\begin{array}{c}1.48 \\
1.18 \times 10^{-1}\end{array}$ & $\begin{array}{r}-4.01 \times 10^{-6} \\
1.66 \times 10^{-5}\end{array}$ & 0.97 & $\begin{array}{c}1.45 \\
1.29 \times 10^{-1}\end{array}$ & $\begin{array}{l}1.24 \times 10^{-5} \\
3.58 \times 10^{-5}\end{array}$ \\
\hline
\end{tabular}




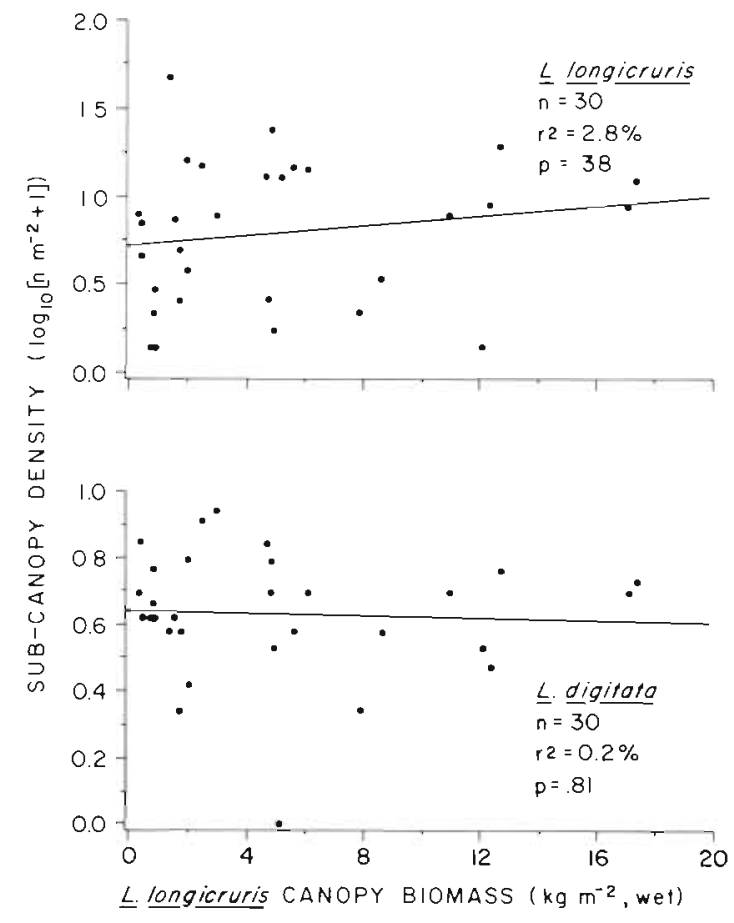

Fig. 9. Effect of Laminaria longicruris canopy $(>311 \mathrm{~cm}$ total length) biomass on density of the most recent year class of $L$. longicruris ( $\leq 311 \mathrm{~cm}$ total length) and $L$. digitata $(<129 \mathrm{~cm}$ total length) developing in the sub-canopy. See Table 4 for parameter estimates

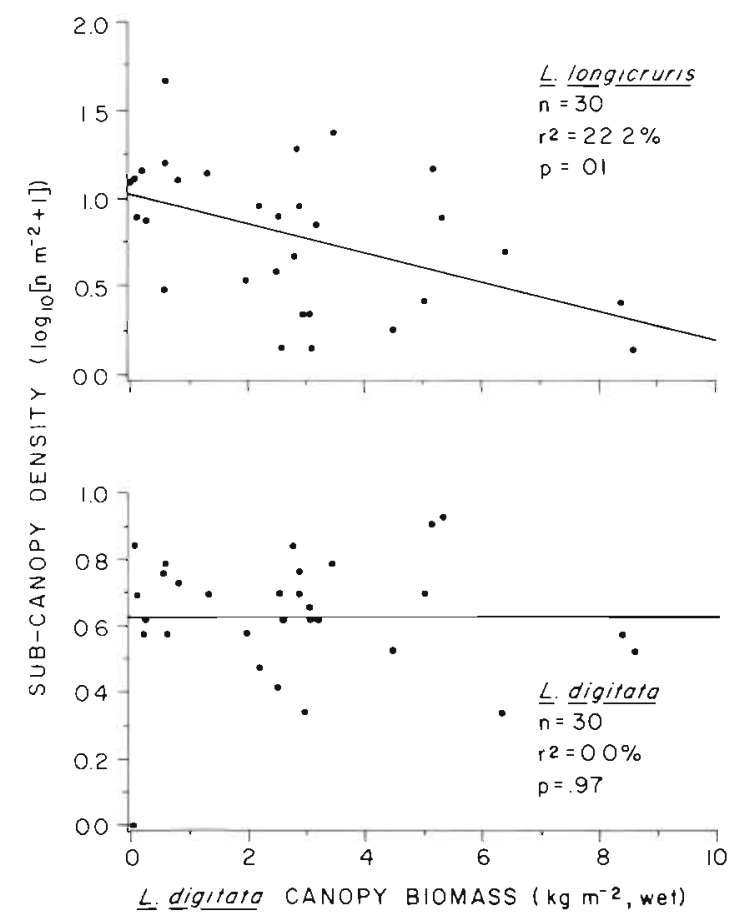

Fig. 10. Effect of Laminaria digitata canopy $(>129 \mathrm{~cm}$ total length) biomass on density of the most recent year class of $L$. longicruris ( $\leq 311 \mathrm{~cm}$ total length) and $L$. digitata ( $\leq 129 \mathrm{~cm}$ total length) developing in the sub-canopy. See Table 4 for parameter estimates ing in the sub-canopy was influenced by the canopy biomass of $L$. longicruris. However, the density of new recruits of $L$. longicruris developing in the sub-canopy is significantly ( $p=0.01$ ) negatively correlated with the canopy biomass of $L$. digitata. L. digitata canopy biomass appears not to affect $L$. digitata sub-canopy density.

Fig. 11 and 12, and Table 5, which are also based on data summarized by transect for all plot-year samples, demonstrate that sub-canopy biomass tends toward an upper limit independent of sub-canopy density at relatively low densities. This relationship probably reflects density-dependent growth, with high densities reducing growth rates. This study has shown earlier (Fig. 6) that standing-crop (and therefore density) reduction arising from a total harvest increases the growth rates of both Laminaria longicruris (1.9 times) and L. digitata (4.3 times) over unharvested populations. The results

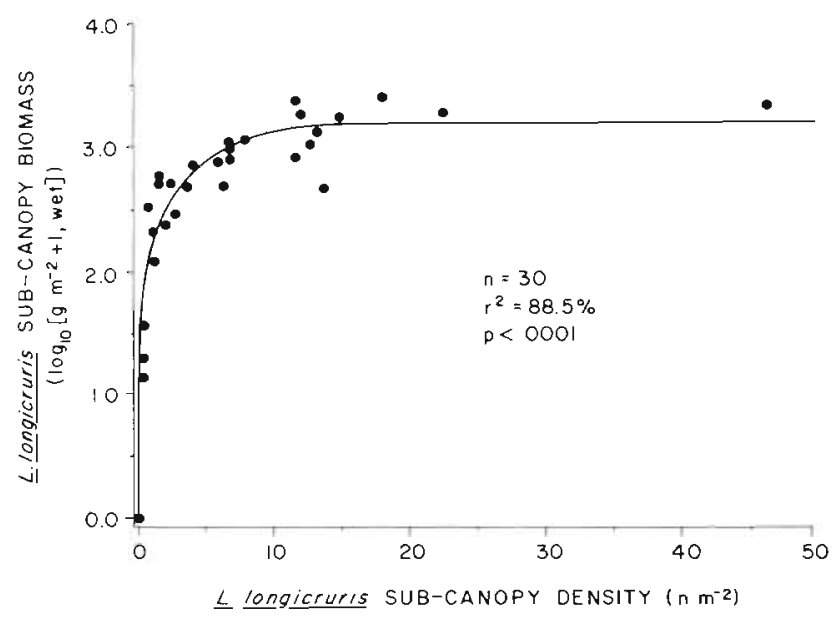

Fig. 11 Laminaria longicruris. Relationship between subcanopy density and sub-canopy biomass. See Table 5 for parameter estimates

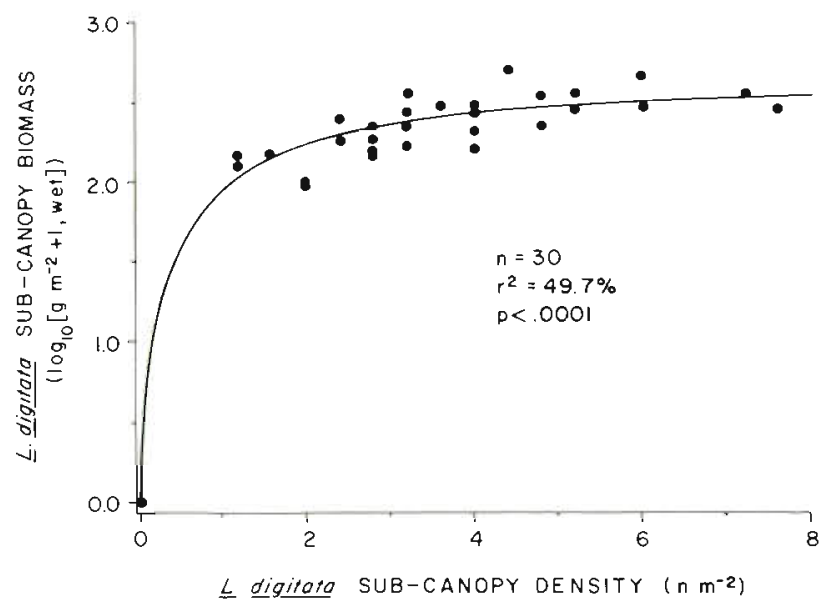

Fig. 12. Laminaria digitata. Relationship between sub-canopy density and sub-canopy biomass. See Table 5 for parameter estimates 
Table 5. Laminaria longicruris and L. digitata. Relationship between sub-canopy density and sub-canopy biomass at Ram Island. The linear model is: 1/ln (sub-canopy biomass $\mathrm{m}^{-2}$, wet, +1$)=j+j\left[1 /\right.$ sub-canopy density $\left.\left(\mathrm{n} \mathrm{m}^{-2}\right)\right]$ for the saturating curve in Fig. $11 \& 12$

\begin{tabular}{|lcc|}
\hline Parameters & L. longicruris & L. digitata \\
\hline $\mathrm{i}$ SE of $\mathrm{i}$ & $1.33 \times 10^{-1}$ & $1.66 \times 10^{-1}$ \\
$1 \mathrm{j}$ & $4.54 \times 10^{-3}$ & $3.90 \times 10^{-3}$ \\
$\mathrm{j}$ SE of $\mathrm{j}$ & $7.55 \times 10^{-2}$ & $5.44 \times 10^{-2}$ \\
$\mathrm{Asymptote}$ & $5.14 \times 10^{-3}$ & $1.05 \times 10^{-2}$ \\
Half-saturation constant & $1 / \mathrm{i}$ & $1 / \mathrm{i}$ \\
$\mathrm{n}$ & 30 & $\mathrm{j} / \mathrm{i}$ \\
$\mathrm{r}^{2}(\%)$ & 88.5 & 40 \\
$\mathrm{p}$ & $<0.0001$ & $<0.0001$ \\
\hline
\end{tabular}

presented in Fig. 11 and 12 support this interpretation.

Although not applied to a monospecific seaweed stand, the saturating curves in Fig. 11 and 12 are theoretically compatable with the concept of the boundary condition known as the $-3 / 2$ power law (Yoda et al. 1963). This condition, which may define a limit to the relationship between mean weight and density for a plant species, has been argued by Cousens \& Hutchings (1983) to apply to seaweeds.

\section{SIMULATION MODEL OF LAMINARIA DYNAMICS}

\section{Development}

The purpose of the model is to (1) predict density and biomass of both species during post-harvest years; (2) calculate expected yields for different harvest policies; and (3) perhaps reveal qualitative changes in the Laminaria community that might occur as a result of a specific harvest policy. For example: could continual annual harvesting of $L$. longicruris only, a practical and perhaps technically preferable strategy, result in the local elimination of $L$. longicruris because of increasing dominance of $L$. digitata?

The model is age-structured with first-year population variables being estimated from the observed data for canopy and sub-canopy plants within H1981. Wet weight-at-age (Fig. $4 \& 5$, Table 3), mortality (Fig. 3, Table 2), and recruitment (Fig. $9 \& 10$, Table 4) parameters estimates are applied logically to the first-year post-harvest populations of both species to estimate the values of population variables for subsequent years. Note that the competitive advantage of Laminaria digitata is expressed in the recruitment function. Sub-canopy (Age 1) biomass is determined from its relationship to sub-canopy density (Fig. 11 \& 12, Table 5). The various harvest policies executed remove standing crop and reduce plant densities. Harvest yield is calculated, and the functional relationships in the model are used to simulate the state of the system the summer following harvesting, based on the state of the system following the harvest. The model includes standard errors for all parameter estimates, and these are incorporated into the model predictions with a random normal deviate. This facilitates the determination of confidence limits for all predictions by Monte Carlo simulations.

\section{Simulation results}

The results produced by the model for a population recovering from a total harvest are presented in Fig. 13, for density. The model predicts that in the absence of harvesting both species should co-exist. That is, the competitive advantage of Laminaria digitata is not sufficient to eliminate $L$. longicruris. For both species the first-year post-harvest predicted and measured (H1981) results are identical by definition, and the predicted second-year post-harvest, and

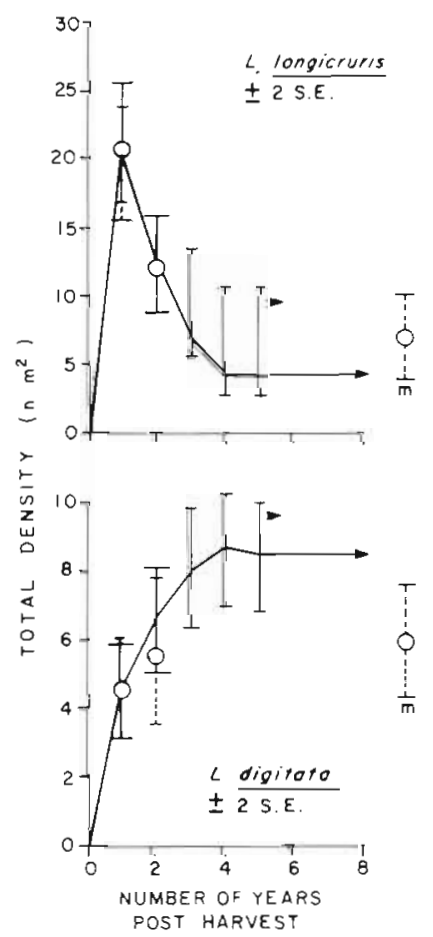

Fig. 13. Laminaria longicruris and L. digitata. Time series predictions for densities based on simulation presented in text. $L$. longicruris density at equilibrium $=4.4$ ind $\mathrm{m}^{-2} ; L$. digitata density at equilibrium $=8.5$ ind $\mathrm{m}^{-2}$. Open circles: densities measured within the harvest plot for Years 1 and 2 post-harvest (H1981, H1982), and within the most mature (m) control plot (C1982) 


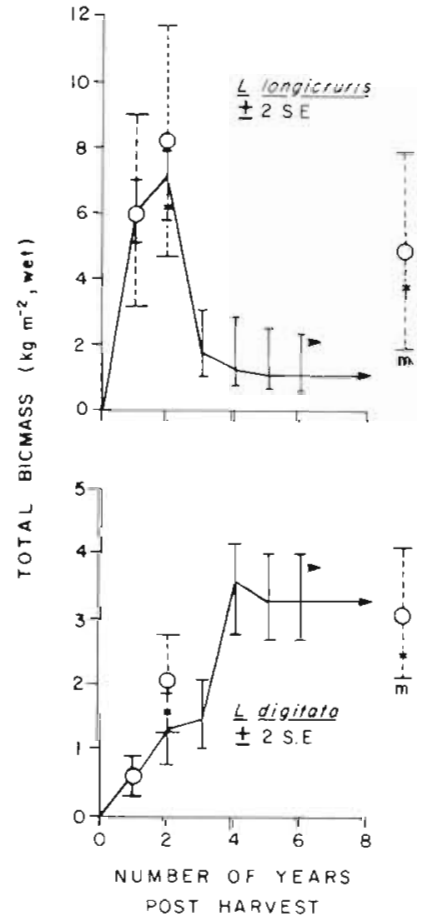

Fig. 14. Laminaria longicruris and $L$. digitata. Time series predictions for biomass based on simulation presented in text. $L$. longicruris biomass at equilibrium $=1.0 \mathrm{~kg} \mathrm{~m}^{2} ; L$. digitata biomass at equilibrium $=3.1 \mathrm{~kg} \mathrm{~m}^{3}$. Open circles: biomass measured within the harvest plot for Years 1 and 2 post-harvest (H1981, H1982), and within the most mature (m) control plot (C1982). Asterisks: measured biomass after being adjusted to account for expected attrition of lamina biomass from mature plants during summer

equilibrium densities, are reasonably close to H1982 and the most mature (m, Fig. 13) control site (C1982), respectively.

In Fig. 14, predicted and measured biomass values for both species are similar, except that the predicted equilibrium biomass value for $L$. longicruris seriously underestimates measured C1982 biomass. The model was designed only to predict the equilibrium biomass following the period of attrition, so an important source of bias in the biomass predictions arises from the plants having been weighed during the early summer, before attrition would have reduced their weight (Smith 1985). The logistic model does not allow plants to exceed the $\mathrm{k}$ parameter (Table 3 ) for maximum plant weight, whereas realistically they exceed this limit during late spring (May-June), followed by attrition during summer (July-September). When the measured biomass values are adjusted to estimate post-attrition biomass using the data contributing to Smith (1985), the difference between the predicted and measured biomass values for $L$. longicruris is reduced. Also, presuming $\mathrm{C} 1982$ to be the most mature plot would be inappropriate if that plot experienced a recent disturbance.

Because predicted and measured results are similar for the first 3 yr post-harvest, the present model may be useful for predicting the results of different harvest policies which perturbate the Laminaria community within the bounds of our knowledge of its dynamics over this time period.

Table 6 presents results of various harvest policies on relative density and biomass of each species. It can be interpreted from Table 6 that the best policy for enhancing Laminaria longicruris is a total harvest of both species each year. This results in a 6.05 times increase in its summer pre-harvest biomass over a noharvest equilibrium. L. longicruris benefits from both a faster growth rate and reduced competition from $L$. digitata. Harvesting $L$. digitata and only the canopy of L. longicruris is not an effective policy, yielding only $11 \%$ of a total harvest, because the high density of $L$. longicruris in the sub-canopy greatly reduces the growth rate of $L$. longicruris and diminishes the advantage of removing the more competitive L. digitata. In

Table 6. Laminana longicruris and $L$. digitata. Relative pre-harvest equilibrium summer densities and biomass for different annual harvest policies. Results based on analysis and simulation of population dynamics at Ram Island

\begin{tabular}{|c|c|c|c|c|}
\hline \multirow[t]{2}{*}{ Harvest policy (removals) } & \multicolumn{2}{|c|}{ Relative densities ${ }^{a}$} & \multicolumn{2}{|c|}{ Relative biomass ${ }^{\mathrm{a}}$} \\
\hline & L. longicruris & L. digitata & L. longicruris & L. digitata \\
\hline No harvest & 1.00 & 1.00 & 1.00 & 1.00 \\
\hline Total harvest & 4.72 & 0.52 & 6.05 & 0.14 \\
\hline L. longicruris only & 0.89 & 1.00 & 0.73 & 1.06 \\
\hline L. longicruris canopy only & 0.98 & 1.00 & 0.98 & 1.02 \\
\hline L. digitata only & 1.93 & 0.40 & 1.62 & 0.08 \\
\hline L. digitata canopy only & 1.35 & 0.70 & 1.28 & 0.59 \\
\hline (L. longicruris + L. digitata) canopy & 1.34 & 0.70 & 1.26 & 0.60 \\
\hline L. longicruris + (L. digitata canopy) & 1.25 & 0.70 & 0.93 & 0.61 \\
\hline L. digitata $+(L$. longicruris canopy) & 1.92 & 0.40 & 1.60 & 0.08 \\
\hline
\end{tabular}


practice, a yield considerably greater than $11 \%$ can probably be achieved by harvesting in the late spring, before most of the summer attrition of biomass occurs. Similarly, the predicted yield of $4 \%$ of a total harvest. when harvesting only the canopy of $L$. longicruris, can be improved by late spring harvest.

Laminaria digitata is not enhanced very much by harvesting. All harvest policies reduce $L$. digitata biomass except those that harvest only L. longicruris, in which case there is a 1.02 to 1.06 times increase in $L$. digitata biomass. There is no indication that continual annual harvesting of only $L$. longicruris will result in increasing dominance of $L$. digitata and the elimination of L. longicruris. Table 7 summarizes the predictions for yield under different harvest policies. If a high total yield, or high yield of either species, is desired, a total harvest every year is the best policy. If a high yield of $L$. digitata is desired, the best policies are those which remove only the canopy of L. digitata. This results in a 3.63 to 3.76 times increase in yield over the total harvest policy. Unfortunately the technology for executing these policies efficiently does not exist. In practice, the increased biological efficiency is probably not sufficient to overcome the technical inefficiencies of a selective harvest.

\section{DISCUSSION}

Observations of changes in recruitment rates following seaweed removal experiments are not new. Likewise, the importance of the concept of competition is well known to seaweed ecologists. The qualitative results reported in this study on the dynamics of
Laminaria longicruris and $L$. digitata are consistent with results obtained for other systems. Increased recruitment success with canopy removal has been observed for several species of Laminariales (Black 1974, Hay \& South 1979, Santelices et al. 1980, Kirkman 1982, Santelices \& Ojeda 1984 b,c). In some of those cases adults of a particular species inhibited recruitment of conspecific juveniles. The data presented in this paper do not suggest that adult Laminaria in this system inhibit the recruitment of conspecific juveniles. The only type of interaction detected was interspecific competition. Alternatively, canopy removal has also resulted in patterns of succession that do not immediately result in increased recruitment by the species removed (Ojeda \& Santelices 1984, Santelices \& Ojeda 1984a, and papers cited therein). This does not appear to be the pattern for this system (Smith 1985).

In seaweed ecology, competition is very often used to explain the results of contests in which there is a winning and losing species (Kain 1979, Hawkins \& Harkin 1985) giving emphasis to the importance of competition for determining the limits of a species' distribution and producing the observed patterns of zonation. The results of this study demonstrate that competition is a dynamic process which occurs continually, but may be balanced by other factors, such as compensatory growth and mortality, thereby permitting competing species to co-exist. In particular, increased growth rates of seaweeds following canopy removal (not to be confused with increased recruitment) probably exists for a number of systems because of the increased availability of space and light, but can be difficult to measure accurately because of the logis-

Table 7. Laminaria longicruris and L. digitata. Predicted annual yields of different harvest policies. Results based on analysis and simulation of population dynamics at Ram Island

\begin{tabular}{|c|c|c|c|c|}
\hline Harvest policy (removals) & $\begin{array}{l}\text { Commerciala } \\
\text { practicality }\end{array}$ & L. longicruris & $\begin{array}{c}\text { Annual yield } \\
\text { L. digitata }\end{array}$ & Total \\
\hline Total & Practical & & & \\
\hline Every year & & 1.00 & 1.00 & 1.00 \\
\hline Every 2 nd year & & 0.55 & 1.31 & 0.60 \\
\hline Every 3rd year & & 0.09 & 0.98 & 0.16 \\
\hline \multicolumn{5}{|l|}{ Every year } \\
\hline L. Ionglcruris only & Impractical & 0.12 & 0.00 & 0.11 \\
\hline L. longicruris canopy only & Practical & 0.04 & 0.00 & 0.04 \\
\hline L. digitata only & Impractical & 0.00 & 0.54 & 0.04 \\
\hline L. digitata canopy only & Impractical & 0.00 & 3.63 & 0.25 \\
\hline (L. longicruris $+L$. digitata) canopy & Impractical & 0.05 & 3.67 & 0.30 \\
\hline L. longicruns $+($ L. digitata canopy) & Impractical & 0.15 & 3.76 & 0.40 \\
\hline L. digitata + (L. longicruris canopy) & Impractical & 0.07 & 0.54 & 0.11 \\
\hline
\end{tabular}


tical problems of tagging very small plants, and the high mortalities that occur both naturally, and as a result of tagging. Approaches similar to the one introduced in this paper may overcome these difficulties for some situations.

For the system studied here the taller, faster growing, and more vulnerable, canopy species - Laminaria longicruris - appears adapted to do well following a disturbance, whereas the shorter canopied, and slower growing $L$. digitata is more competitive and apparently better adapted to persist through time. Dayton (1985) reports that a similar pattern of adaptive morphology has been observed for other kelp guilds. This feature may explain some of the year-to-year variation in standing crop for unharvested populations of L. longicruris and L. digitata (Table 1). The location of this study is subject to storms and ice scouring during winter causing plant mortalities (Smith 1985). This study predicts increased success of $L$. longicruris following a disturbance because of reduced standing crop and plant densities, as Ojeda \& Santelices (1984) observed for Lessonia nigrescen. L. digitata would have a standing crop lower than that expected at equilibrium. The higher than expected standing crop of $L$. longicruris, and lower than expected standing crop of L. digitata, in $(\mathrm{H}+\mathrm{C}) 1980, \mathrm{C} 1981$ and C1982 may be due to a recent winter disturbance. This same argument implies that predicted equilibrium density and biomass values can be attained only if the system is free of disturbances for several years, and that at most times the system will not be at equilibrium.

On a broad perspective, literature addressing the demographics of seaweed populations is common, for good reason (Dayton 1985). Seaweeds are components of relatively dynamic systems, with many species having fast growth rates, high fecundity, and high mortality rates. Therefore, population changes can be observed over relatively short periods of time. However, most of the demographic studies which dominate the seaweed-ecology literature report their results as time series, with no documentation of functional relationships between system components. Anticipated relative changes in population features following complete removal experiments are well documented, but without knowledge of the functional relationships between species, and between life stages within a species, it is not feasible to predict the degree or permanency of changes, or yield expectations, resulting from a change in a system state, unless that particular state was observed experimentally, e.g. a total harvest. An exception to this tendency are some recent analyses of the relationships between recruitment success and the inter-plant distances of adult plants (Dayton et al. 1984, Santelices \& Ojeda 1984c), and plant size (Velimirov \& Griffiths 1979).
If the important functional relationships within and between populations are recognized, i.e. those interspecific and intraspecific interactions that account for most of the observed phenomena, then it is possible to formulate predictions based on a contemporary understanding of the population dynamics. This is not easily achieved in many systems because too many interacting species preclude an unequivocal interpretation of apparent functional relationships between population variables. Fortunately, the Laminaria-dominated seaweed community in southwestern Nova Scotia is well suited to this type of approach and analysis. With only 2 species comprising the kelp overstory, information on their population dynamics and interspecific interactions was relatively easily acquired. The experimental and sampling design was effective in obtaining parameter estimates because the plot sizes of $500 \mathrm{~m}^{2}$ were large enough to allow replication of samples and estimation of parameter variance for the important relationships. Studies which rely on much smaller plots may not provide sufficient replication and may not eliminate boundary effects which can strongly influence the outcomes of perturbations (Dayton et al. 1984, Dayton \& Tegner 1984, Sousa 1984). They possibly also would have little management utility in that they might not provide enough information for statistical evaluation of the predicted and measured results of various harvest policies based on contemporary knowledge of the system's dynamics.

The consideration of scale has recently been the focus of attention for resource management scientists. For example, Hilborn \& Walters (1981) point out the pitfalls of relying on small scale perturbations, field, and laboratory studies, to provide scientific advice for formulating harvest policies. It generally turns out to be inappropriate to 'scale-up' information obtained in this manner and then presume to understand larger scale dynamics. They strongly endorse the concept of 'experimental management', and point out the potential rewards of deliberately altering harvest policies to create large-scale perturbations in order to learn more about a system's dynamics. Walters \& Hilborn (1978) argue that many contemporary harvest policies, for a number of different resources, are conservative in that they tend toward maintaining stable population parameters. Thus, they do not provide an opportunity to learn more about a system's behaviour. Likewise, nature does not always provide enough experimental variability. Deliberate manipulation of harvest policies is required in order to improve our understanding of a system. They call this approach 'adaptive probing'

There is an element of biological and economic risk when undertaking such an approach. Adaptive probing experiments should be not performed without knowledge of the risks and potential rewards, and 
some preconception of the anticipated results. In this sense the predictions made by the simulation model in this study are hypotheses which need to be tested in order to measure the degree of compliance between predicted and measured results. An experimental management approach would advocate that various meso-scale (several ha) perturbations of the Laminaria system under consideration be performed following pre-harvest assessments. The dynamics should be monitored and harvest yield determined. A significant departure from a prediction should not be considered a failure, but a contribution to our understanding of the system.

Acknowledgements. Many thanks to several summer employees who are responsible for most of the field data collection. I also express my gratitude, in particular, to Messrs. Andrew Bagnall, Greg Roach, and Glen Varen who participated in the field work all year-round. Computer facilities and support services were kindly provided by the Pacific Biological Station. The reviews and criticisms of the manuscript by Drs. Paul Breen and Susan Swarbrick of P.B.S. and 3 anonymous referees are much appreciated.

\section{LITERATURE CITED}

Black, R. (1974). Some biological interactions affecting intertidal populations of the kelp Egregia laevigata. Mar. Biol. 28: $189-198$

Cassie, R. M. (1954). Some uses of probability paper in the analysis of size frequency distributions. Aust. J. mar. Freshwat. Res. 5: 513-522

Chapman, A. R. O. (1984). Reproduction, recruitment and mortality in two species of Laminaria in southwest Nova Scotia. J. exp. mar. Biol. Ecol. 78: 99-109

Cousens, R., Hutchings, M. J. (1983). The relationship between density and mean frond weight in monospecific seaweed stands. Nature, Lond. 301: 240-241

Dayton, P. K. (1985). Ecology of kelp communities. A. Rev. Ecol. Syst. 16: 215-245

Dayton, P. K., Tegner, M. J. (1984). The importance of scale in community ecology: a kelp forest example with terrestrial analogs. In: Price, P. W., Slobodchikoff, C. N., Gaud, W. S. (ed.) A new ecology: novel approaches to interactive systems. John Wiley and Sons, New York, p. 457-481

Dayton, P. K., Currie, V., Gerrodette, T., Keller, B. D., Rosenthal, R., Tresca, D. V. (1984). Patch dynamics and stability of some California kelp communities. Ecol. Monogr. 54: $253-289$

Foreman, R. E. (1977). Benthic community modification and recovery following intensive grazing by Strongylocentrotus droebachiensis. Helgoländer wiss. Meeresunters. 30: $468-484$
Hawkins, S. J., Harkin, E. (1984). Prelıminary canopy removal experiments in algal dominated communities low on the shore and in the shallow subtidal on the Isle of Man. Botanica mar 28: 223-230

Hay, C. H., South, G. R. (1979). Experimental ecology with particular reference to proposed commercial harvesting of Durvillaea (Phaeophyta, Durvilleales) in New Zealand. Botanica mar. 22: 431-436

Hilborn, R., Walters, C. J. (1981). Pitfalls of environmental baseline and process studies. Environ. Impact Assess. Rev. 2: 265-278

Kain, J. M. (1979). A view of the genus Laminaria. Oceanogr. mar. Biol. A. Rev. 17: 101-161

Kirkman, H. (1982). The first year in the life history and the survival of the juvenile marine macrophyte, Ecklonia radiata (Turn.) J. Agardh. J. exp. mar. Biol. Ecol. 55: $243-254$

Mann, K. H. (1973). Seaweeds: their productivity and strategy for growth. Science 182: 975-981

Ojeda, F. P., Santelices, B. (1984). Ecological dominance of Lessonia nigrescens (Phaeophyta) in central Chile. Mar. Ecol. Prog. Ser. 19: 83-91

Santelices, B., Ojeda, F. P. (1984a). Effects of canopy removal on the understory algal community structure of coastal forests of Macrocystis pyrifera from southern South America. Mar. Ecol. Prog. Ser. 14: 165-173

Santelices, B., Ojeda, F. P. (1984b). Population dynamics of coastal forests of Macrocystis pyrifera in Puerto Toro, Isla Navarino, southern Chile. Mar Ecol. Prog. Ser 14: $175-183$

Santelices, B., Ojeda, F. P. (1984c). Recruitment, growth and survival of Lessonia nigrescens (Phaeophyta) at various tidal levels in exposed habitats of central Chile. Mar. Ecol. Prog. Ser. 19: 73-82

Santelices, B., Castilla, J. C., Cancino, J., Schmiede, P. (1980). Comparative ecology of Lessonia nigrescens and Durvillaea antarctica (Phaeophyta) in central Chile. Mar Biol. 59: $119-132$

Smith, B. D. (1985). Recovery following experimental harvesting of Laminaria longicruris and L. digitata in southwestern Nova Scotia. Helgoländer Meeresunters. 39: 83-101

Sousa, W. P. (1984). The role of disturbance in natural communities. A. Rev. Ecol. Syst. 15: 353-391

Velimirov, B., Griffiths, C. L. (1979). Wave-induced kelp movement and its importance for community structure. Botanica mar. 22: 169-172

Walters, C. J., Hilborn, R. (1978). Ecological optimization and adaptive management. A. Rev. Ecol. Syst. 9: 157-188

Wharton, W G., Mann, K. H. (1981). Relationship between destructive grazing by the sea urchin, Strongylocentrotus droebachiensis, and the abundance of American lobster, Homarus americanus, on the Atlantic coast of Nova Scotia Can. J. Fish. Aquat. Sci. 38: 1339-1349

Yoda, K., Kua, T., Ogawa, H., Hozumi, K. (1963). Self-thinning in over-crowded pure stands under cultivated and natural conditions. J. Biol. Osaka City Univ. 14: 107-129 